\title{
Pengaruh Religiusitas dan Persepsi Nasabah terhadap Keputusan Memilih Bank Syariah
}

\author{
Muhammad Zuhirsyan \\ Nurlinda \\ Prodi Keuangan dan Perbankan Syariah Jurusan Akuntansi \\ Politeknik Negeri Medan \\ Email: zuhirsyan12@gmail.com; a24linda@gmail.com
}

\begin{abstract}
Abstrak
Penelitian ini bertujuan untuk mengetahui pengaruh religiusitas dan persepsi para nasabah Perbankan Syariah dalam menentukan pilihan menjadi nasabah di BRI Syariah. Penelitian ini dilakukan untuk melihat seberapa besar pengaruh religiusitas dan persepsi terhadap keputusan memilih perbankan syariah di PT. BRI Syariah di Medan. Jenis penelitian ini adalah penelitian kausal dengan metode pengumpulan data menggunakan metode survey dan teknik pengumpulan data menggunakan teknik kuisioner serta sampel dipilih secara random sampling. Pengolahan data akan dibantu dengan alat analisis data untuk menjawab apakah terdapat pengaruh yang signifikan tingkat religiusitas terhadap keputusan memilih bank syariah pada PT. BRI Syariah KC. S. Parman serta Apakah terdapat pengaruh yang signifikan persepsi terhadap keputusan memilih bank syariah pada PT. BRI Syariah KC. S. Parman. Hasil penelitian menunjukkan, secara simultan religiusitas dan persepsi nasabah berpengaruh secara signifikan terhadap keputusan memilih bank syariah. Sementara secara parsial, hanya variable religiusitas yang memiliki pengaruh positif dan signifikan terhadap keputusan memilih bank syariah.
\end{abstract}

Kata Kunci: Religiusitas, Persepsi Calon Nasabah, Keputusan Memilih, Bank Syariah

\begin{abstract}
The purpose of this research is to determine the influence of religiosity and perceptions of sharia banking customers in determining the choice of becoming a customer at BRI Syariah. This research was conducted to measure the influence of religiosity and perceptions on the decision of choosing sharia banking in PT. BRI Syariah in Medan. The type of this research is causal research with data collection method using survey method and data collection technique using questionnaire technique and sample is choosen by random sampling. Data processing using data analysis tool to answer whether there is a significant influence the level of religiosity to the decision of choosing Islamic banks at PT. BRI Syariah KC. S. Parman and is there any significant influence perception on decision of choosing sharia bank at PT BRI Syariah KC. S. Parman. The results showed, simltaneously the religiosity and perception of customers significantly influence the decision to choose Islamic banks. While partially, only variable religiosity has a positive and significant influence on the decision to choose Islamic banks.
\end{abstract}

Keywords: Religiosity, perception of Prospective Customers, Decision of Choosing, Sharia Bank 


\section{Pendahuluan}

Perkembangan ekonomi syariah ditandai dengan meningkatkan lembaga keuangan syariah dan lembaga bisnis syariah. Selain itu, pertumbuhan ekonomi syariah secara akademik ditandai dengan maraknya pembukaan konsentrasi ekonomi syariah di perguruan tinggi Islam atau umum, juga merebaknya lembaga dan organisasi yang konsen pada kajian dan pengembangan ekonomi syariah.

Dalam SK Menkeu RI No. 792 Tahun 1990, Lembaga Keuangan adalah suatu badan yang kegiatannya bidang keuangan, melakukan penghimpunan dan penyaluran dana kepada masyarakat terutama guna membiayai investasi peusahaan. Meski dalam peraturan tersebut lembaga keuangan diutamakan untuk membiayai investasi perusahaan, namun tidak berarti membatasi kegiatan pembiayaan lembaga keuangan. Dalam kenyatannya, kegiatan usaha lembaga keuangan bisa diperuntukkan bagi investasi perusahaan, kegiatan konsumsi dan kegiatan distribusi barang dan jasa. (Sumitra, 2010: 2728).

Salah satu bidang LKS yang berkembang di Indonesia adalah Bank Syariah. Bank syariah ibarat merupakan solusi bagi kaum muslimin yang ingin menghindari diri dari praktek perbankan konvensional yang menerapkan praktik riba dalam operasional kegiatannya. Lembaga keuangan diatur dalam UU No. 7 Tahun 1992 tentang Perbankan juncto UU No. 10 Tahun1998 tentang Perubahan Atas UU No. 7 Tahun 1992 tentang Perbankan dan UU No. 23 Tahun 1999 tentang Bank Indonesia juncto UU No. 3 Tahun 2004 tentang Bank Indonesia. (Anshari, 2008:15) Sementara untuk perbankan syariah diatur dalam Undang-Undang No. 21 Tahun 2008. Dalam UU terakhir ini tersirat bahwa prinsip syariah mencakup aturan perjanjian berdasarkan hukum Islam antara Bank dan pihak lain untuk melakukan penyimpanan dana dan/atau pembiayaan kegiatan usaha, atau kegiatan lainnya yang dinyatakan sesuai dengan Syariah, antara lain, pembiayaan berdasarkan prinsip bagi hasil (mudharabah), pembiayaan berdasarkan prinsip penyertaan modal (musharakah), prinsip jual beli barang dengan memperoleh keuntungan (murabahah), atau pembiayaan barang modal berdasarkan prinsip sewa murni tanpa pilihan (ijarah), atau dengan adanya pilihan pemindahan kepemilikan atas barang yang disewa dari pihak Bank oleh pihak lain (ijarah wa iqtina). Perbankan syariahpun semakin diakui dengan pemberlakuan UU No. 21 Tahun 2008. UU ini mengokohkan kedudukan perbankan syariah di Indonesia. (Mardani, 2015: 2).

Ada dua model pembiayaan yang disalurkan dalam perbankan syari'ah; pertama, equity financing dengan menggunakan dua prinsip yaitu mudharabah dan musyarakah atau dikenal dengan profit and loss sharing. Yaitu bank syari'ah akan memperoleh keuntungan berupa bagi hasil, dari proyek yang dibiayai olehnya. Apabila proyeknya rugi, maka kerugian itu akan ditanggung bersama antara bank dan debitur (usahawan). Kedua, debt financing dalam bentuk jual beli dan sewa. Sistem murabahah adalah sistem yang dominan dalam hal ini, disamping sistem lainnya seperti ba'i salam, istishna' dan al ijarah.

Akad investasi yang dibuat bedasarkan sistem mudharabah dan musyarakah adalah kontrak/akad yang tidak memberikan kepastian pendapatan (return), kontrak ini disebut dengan natural uncertainty contracts. Ketidakpastian ini bisa terjadi dari segi jumlah (amount) maupun waktu (timing)-nya. Tingkat return-nya bisa positif, negatif dan nol. Investasi dengan menggunakan kontrak seperti ini secara lahiriyah tidak menawarkan return yang tetap dan pasti (unfixed and unpredeterminent). ${ }^{1}$

Metawa, S. A., \& Almossa (1998), meneliti tentang perilaku nasabah Islamic Bank di Bahrain menemukan bahwa keputusan nasabah dalam memilih bank

\footnotetext{
${ }^{1}$ A. Karim, Adiwarman. 2014. Bank Islam: Analisis Fiqih dan Keuangan. Jakarta: PT Rajagrafindo Persada
} 
syariah lebih didorong oleh faktor keagamaan melalui dukungan masyarakat pada ketaatan perbankan terhadap prinsip-prinsip Islam. Di samping itu masyarakat di negara tersebut juga dipengaruhi oleh dorongan keluarga, dan teman serta lokasi keberadaan bank. Namun Penelitian yang dilakukan oleh Irbid dan Zarka (2001) memberikan kesimpulan yang berbeda tentang faktor yang mendorong nasabah memilih bank konvensional atau bank syariah. Mereka justru menemukan bahwa motivasi nasabah dalam memilih bank syariah cenderung didasarkan kepada motif keuntungan, bukan kepada motif keagamaan.

Selanjutnya, penelitian Pusat Studi Ekonomi Islam Dan Bisnis Brawijaya Malang (2000) di Jawa Timur Kerjasama Bank Indonesia dan Center for Banking Research Universitas Andalas ${ }^{2}$, mendukung bahwa perbedaan penting dalam memilih bank terletak pada faktor kelompok acuan, peran dan status, kepraktisan dalam menyimpan kekayaan, ukuran produk, jaminan, dan periode pembayaran. Sedangkan terkait persepsi, Penelitian tentang persepsi konsumen di Malaysia menemukan bahwa persepsi konsumen terhadap bank syariah terdiri terdiri dari beberapa dimensi yang terdiri; a) pemanfaatan fasilitas perbankan; b) pengetahuan terhadap perbankan Islam; c) peranan konsumen dalam memilih produk perbankan (Nurafifah dan Haron 2001). Almossawi (1991) di Bahrain mengidentifikasi lima atribut penting yang dipertimbangkan konsumen dalam memilih bank; (a) lokasi ATM yang mudah dijangkau, (b) ketersediaan ATM dibeberapa lokasi, (c) reputasi bank, (d) layanan ATM 24 jam, dan (e) ketersediaan tempat parkir yang memadai. Sedangkan penelitian (Rivai et al., 2006) dan (Rohmadi, Nurbaiti, \& Junaidi, 2016) menemukan bahwa keputusan memilih nasabah lebih pada faktor internal yang terdiri

${ }^{2}$ Rivai, H., Luviarman, N., \& Dkk. (2006). Identifikasi Faktor Penentu Keputusan Konsumen dalam Memilih Jasa Perbankan: Bank Syariah vs Bank konvensional. Kerjasama BankIndonesia Dan Center for Banking Research Universitas Andalas, 1-17. dari 1) persepsi, (2) biaya dan manfaat, dan (3) agama. Faktor-faktor seperti pengetahuan, religiusitas, produk, reputasi dan pelayanan di Bank Syariah memiliki pengaruh positif terhadap keputusan memilih menabung di Bank Syariah, meskipun tidak signifikan (Abhimantra, Maulina, \& Agustianingsih, 2013). Sedangkan (Hanik \& Handayani, 2014) menemukan bahwa Hasil dari penelitian mereka menunjukkan bahwa variabel yang berpengaruh signifikan terhadap Keputusan Memilih Perbankan Syariah adalah Produk, Harga, Promosi, Tempat, Faktor Sosial dan Faktor Personal.

Oleh karena itu, meneliti tentang pemahaman agama dan persepsi masyarakat tentang memilih suatu hal yang diinginkannya menjadi menarik. Penelitian ini juga merupakan replikasi penelitan yang dilakukan oleh (Rohmadi, Nurbaiti, \& Junaidi, 2016) dengan mengembangkan variabel yang merujuk pada saran yang diberikan. Mereka menggulirkan pertanyaan terkait apakah perilaku konsumen dalam memilih jenis bank tersebut juga dipengaruhi oleh tipe dan varian produk yang ditawarkan oleh setiap jenis bank? Studi yang telah dilakukan juga belum memberikan penekanan terhadap jenis nasabah (individu versus institusional) di dalam memahami persepsi mereka terhadap keberadaan ke dua jenis bank sehingga studi lanjutan diperlukan . Dalam hal ini keinginan atau tujuan untuk memilih perbankan syariah sebagai solusi dari sikap menghindari muamalah yang berkontens ribawi apakah merupakan factor yang dominan?. Untuk itu, perlu dilakukan penelitian untuk melihat seberapa besar pengaruh religiusitas dan perspesi terhadap keputusan memilih perbankan syariah di PT. Bank Republik Indonesia Syariah di Medan.

\section{Pembahasan}

\section{Telaah Pustaka}

Religi berasal dari kata religio (latin) yang dasar katanya adalah religare yang berarti mengikat. Sedangkan dalam bahasa Arab disebut tadayyun yang bermakna 
wara'un, taqwa yang berarti "bersikap berhati-hati, taat" (Al-Mawarid, 1988:774).

Faisal Ismail

(2007:28)

mengemukakan, kata religie berasal dari bahasa Belanda, dan bahasa Inggrisnya adalah religion. Kedua kata ini berasal dari bahasa induk yaitu bahasa latin religare. Lactancius mendefinisikan kata religare sebagai "mengikat menjadi satu dalam suatu persatuan bersama". Menurut Gazalba (dalam Ismail, 2007: 32), kata agama merupakan sinonim dari kata religie.

Selanjutnya, kata keagamaan mengacu pada suatu keadaan yang bersifat religius dan bernuansa ketundukan kepada Tuhan, yakni percaya kepada adanya Tuhan serta mengikuti ajaran yang ditetapkan-Nya. (W.J.S Poerwadarminta, 2011:18). Dalam terminologi para ahli syariat, agama atau keagamaan biasanya diartikan suatu peraturan Tuhan yang mendorong jiwa seseorang yang memiliki akal untuk berpegang teguh pada peraturan-Nya dengan kehendaknya sendiri untuk mencapai kebahagiaan hidup di dunia dan kebahagiaan hidup di akhirat. (Thaib Thahir Abd. Mu'in 1986, dalam Abuddin Nata 2011:222).

Muhammad Bakar Ismail (2008:7) Agama secara bahasa adalah patuh dan tunduk. Oleh karena itu makna agama yang diridhai Allah bagi para hambaNya adalah patuh dan tunduk.

Menurut Nur Ahmad Fadhil Lubis (2010:2), din yang di dalam bahasa Arab adalah agama ternyata memiliki defenisi yang lebih luas. Setiap kata yang terdiri huruf dalya-nun dalam bahasa Arab, mengandung pengertian hubungan dua pihak. Seperti kata dain yang berarti hutang, demikian juga dengan kata dana atau yadinu yang artinya menghukum, yang menunjukkan adanya hakim dan terdakwa. Kata din sendiri mengandung makna hubungan antara dua pihak, di mana pihak pertama mempunyai kedudukan lebih tinggi dari pihak yang kedua. Jika arti kata din seperti tersebut di atas, kemungkinan hubungan yang terjadi ada tiga pola relasi. Pertama, hubungan manusia dengan Allah. Kedua, hubungan manusia dengan manusia dan Ketiga, hubungan manusia dengan alam. Menurut Elizabeth K. Nottingham (dalam Jalaluddin 2000:225-226) agama adalah gejala yang begitu sering "terdapat di mana-mana", dan agama berkaitan dengan usaha-usaha manusia untuk mengukur kedalaman makna keberadaan diri sendiri dan keberadaan alam semesta. Selain itu, agama dapat membangkitkan kebahagiaan batin yang paling sempurna, dan perasaan takut serta ngeri. Agama sebagai bentuk keyakinan manusia terhadap sesuatu yang bersifat Adikodrati (Supernatural) ternyata seakan menyertai manusia dalam ruang lingkup kehidupan yang luas. Agama memiliki nilai-nilai bagi kehidupan manusia sebagai orang per orang maupun dalam hubungannya dengan kehidupan bermasyarakat. Selain itu agama juga memberi dampak bagi kehidupan sehari-hari.

Sikap keberagaman pada orang dewasa memiliki perspektif yang luas didasarkan atas nilai-nilai yang dipilihnya, pendalaman pengertian dan perluasan pemahaman tentang ajaran agama yang dianutnya, merupakan sikap dan bukan sekedar ikut-ikutan (Jalaluddin, 2000:95).

Makna agama secara material adalah "religiusitas" makna ini sering malah terabaikan oleh kita yang memahami agama sebagai sesuatu secara formal semata (Jalaluddin, 2000:12).

Religiusitas pada dasarnya merupakan perbuatan seseorang yang berhubungan dengan masyarakat luas dalam rangka mengembangkan kreativitas pengabdian (ibadah) kepada Allah semata. Dari pengertian dan dimensi religiusitas diatas, maka sesungguhnya religiusitas bisa digambarkan adanya konsistensi antara kepercayaan terhadap agama sebagai unsur kognitif, perasaan agama sebagai unsur efektif dan perilaku terhadap agama sebagai unsur psikomotorik. (Rahmat, 1996:137). Jadi Religiusitas merupakan integrasi secara komplek antara pengetahuan agama, perasaan serta tindakan keagamaan dalam diri seseorang. 
Religiusitas diwujudkan dalam berbagai sisi kehidupan manusia. Aktifitas beragam bukan hanya terjadi ketika seseorang melakukan perilaku ritual (beribadah), akan tetapi juga ketika melakukan aktivitas lainnya yang didorong oleh kekuatan akhir (secara intrinsik). Bukan hanya berkaitan dengan yang tampak dan dapat dilihat mata tetapi juga aktivitas yang tidak tampak dan terjadi dalam hati seseorang.

\section{Aspek-aspek Religiusitas}

Keadaan religiusitas seseorang dipengaruhi beberapa faktor, menurut Daradjat (1982:13) mengemukakan dua faktor, yaitu faktor perkembangan yang berhubungan dengan perkembangan psikis yang dilalui sesorang, serta faktor lingkungan yang merupakan faktor luar yang mempengaruhi kehidupan beragama yakni keluarga, sekolah masyarakat dan latar belakang keagamaan. Sementar itu, sejalan dengan pandangan Islam, Syaltut (2001:7) mengemukakan, religiusitas dalam ajaran Islam teridiri dari tiga bagian, yaitu: akidah (kepercayaan dan keimanan), syariah (hukum-hukum agama yang meliputi ibadah dan muamalah), dan akhlak (budi pekerti).

Menurut Sunaryo mengatakan bahwa dalam pelaksanaan ajaran agama Islam dikenal lima aspek religiusitas, yaitu: a) Aspek Iman yaitu menyangkut keyakinan dan hubungan manusia dengan Tuhan, Malaikat, para Nabi dan sebagainya. b) Aspek Islam yaitu menyangkut frekuensi, intensitas pelaksanaan ibadah yang telah ditetapkan, misalnya: shalat, zakat, puasa dan haji. c) Aspek Ihsan yaitu menyangkut pengalaman dan perasaan tentang kehadiran Tuhan, takut larangan dan sebagainya. d) Aspek Ilmu yaitu menyangkut pengetahuan seseorang tentang ajaran agamanya. Misalnya pengetahuan tentang fiqh, tauhid dan sebagainya. e) Aspek Amal yaitu menyangkut bagaimana tingkah laku seseorang dalam kehidupan bermasyarakat. Misalnya menolong orang lain, membela orang yang lemah dan sebagainya.
Hal di atas diperkuat dengan pendapat tersebut Nurcholish Madjid, dkk (2001:34) menemukan lima faktor keberagaman yaitu; a) Iman, yaitu keyakinan dan hubungan dengan Tuhan beserta perkara ghaib dalam ajaran agama. b) Islam, yaitu frekuensi dan intensitas pelaksanaan ibadah. c) Ihsan, yaitu pengalaman, perasaan dan pengahayatan seseorang. d) Ilmu, yaitu pengetahuan seseorang tentang ajaran agamanya. e) Amal, yaitu perilaku seseorang dalam kehidupan sosial.

\section{Pengertian Persepsi}

Persepsi pada hakikatnya adalah proses kognitif yang dialami oleh setiap orang di dalam memahami informasi tentang lingkunganya, baik lewat penglihatan, pendengaran, penghayatan, perasaan dan penciuman. Jadi kunci untuk memahami persepsi terletak pada pengenalan bahwa persepsi itu merupakan suatu penafsiran yang unik terhadap situasi, dan bukannya suatu pencatatan yang benar terhadap situasi. Hal ini sesuai dengan pendapat David Krech (dalam Thoha, 1997:138) bahwa peta kognitif itu bukanlah penyajian potografik dari suatu kenyataan fisik, melainkan agak bersifat konstruksi sesuai dengan kepentingan utamanya dan dipahami menurut kebiasaannya. Setiap pemahaman adalah pada tingkat tertentu bukanlah seniman yang representatif, karena lukisan gambar tentang kenyataan itu hanya menyatakan pandangan realitas individu.

Kata persepsi memiliki beberapa makna. Menurut Sarwono (1992:45) persepsi dalam pengertian psikologi adalah proses pencarian informasi untuk dipahami. Alat untuk memperoleh informasi tersebut adalah penginderaan (penglihatan, pendengaran, peradaban dan sebagainya). Persepsi merupakan suatu proses yang terjadi pada seseorang yaitu proses memahami atau memberi makna terhadap setiap informasi yang terima oleh seseorang melalui alat indera, dan selanjutnya seseorang mempersepsikan atau memahami informasi 
yang mereka terima. Penjelasan ini menunjukkan bahwa salah satu fungsi adalah untuk membantu orang memahami setiap informasi yang datang dari luar indera.

Selanjutnya Thoha (1997:139-140) mengemukakan bahwa secara ringkas pendapat Krech tersebut dapat disimpulkan bahwa persepsi adalah suatu proses kognitif yang komplek dan manghasilkan suatu gambar unik tentang kenyataan yang barangkali sangat berbeda dari kenyataannya. Berkaitan dengan itu, Mar'at (dalam Jalaluddin 2000:187) menjelaskan bahwa faktor pengalaman dan faktor proses belajar atau sosialisasi mempengaruhi persepsi karena akan memberikan bentuk dan struktur terhadap apa yang dilihat, faktor pengetahuan dan cakrawala akan mempengaruhi seseorang dalam berpersepsi. Persepsi dibentuk oleh imajinasi, karena dengan imajinasi akan memberikan pada kita pengetahuan tentang dunia luar. Seiring dengan itu, Sarwono (1992:51) mengemukakan bahwa persepsi tidak bersifat statis melainkan bisa berubahubah.

Hammer dan Organ (dalam Indrawijaya, 2002:45) mendefinisikan persepsi sebagai suatu proses saat seseorang mengorganisasikan suatu objek dalam pikirannya, menafsirkan, mengalami dan mengolah pertanda atau segala sesuatu yang mempengaruhi perilaku yang akan dipilih. Berdasar pada pendapat tersebut, maka Indrawijaya menarik suatu kesimpulan bahwa ada tiga unsur utama yang terjadi pada proses kognitif yaitu: (1) proses kognisi, (2) proses belajar, dan (3) proses pemecahan persoalan atau pemilihan perilaku. Lebih jauh Indrawijaya menguraikan tahapan-tahapan terjadinya proses persepsi yang meliputi proses masukan, selektivitas dan penutupan.

Secara umum persepsi juga dapat dikatakan suatu bentuk pengamatan terhadap lingkungan dengan menggunakan pengindaraan (panca indera) yang kemudian dikoordinasikan dalam syaraf otak yang kemudian dikaitkan dengan pengalaman dan pengetahuan sehingga manusia dapat mengetahui dan mengenal serta menilai lingkungannya.

Proses pembentukan persepsi merupakan pemaknaan hasil pengamatan yang diawali dengan adanya stimuli. Setelah mendapat stimuli, selanjutnya akan terjadi seleksi yang berinteraksi dengan interpretasi. Proses seleksi terjadi pada saat seseorang memperoleh informasi, maka akan berlangsung proses penyeleksian pesan tentang yang mana pesan yang dianggap penting dan tidak penting. Hasil seleksi tersebut akan disusun menjadi satu kesatuan yang berurutan dan bermakna.

Ada dua kategori yang dapat dipersepsikan masyarakat terhadap memilih menjadi nasabah bank syariah ini, yaitu:

a. Islam dan bank syariah. Persepsi masyarakat dapat diketahui dari pemahaman masyarakat tentang hubungan antara Islam sebagai sebuah agama yang mengajarkan segala yang baik yang berasal dari Tuhan dengan perbankan syariah. Masyarakat dapat memahami keterlibatan ajaran agama Islam dalam setiap kegiatan di dalam perbankan syariah.

b. Fungsi dan eksistensi perbankan syariah. Masyarakat memahami tentang fungsi dan eksistensi perbankan syariah bukan hanya sebagai tempat menabung atau transaksi islami saja tetapi juga tempat untuk meningkatkan nilai-nilai ibadah.

Dari uraian di atas dapat disimpulkan bahwa persepsi masyarakat terhadap keputusan memilih perbankan merupakan proses memaknai objek persepsi yaitu perbankan syariah, baik kongkret maupun tidak dan hal ini dipengaruhi oleh pengetahuan berupa informasi, pengalaman, motivasi dan keinginan yang sesuai dengan kebutuhannya.

\section{Bank Syariah}

Istilah lain yang digunakan untuk sebutan Bank Syariah adalah Bank Islam. Secara akademik, istilah Islam dan Syariah memang mempunyai pengertian yang berbeda. Namun secara teknis untuk penyebutan Bank Islam dan Bank Syariah mempunyai 
pengertian yang sama. (Suwito, 2004: 5) Dilihat dari katanya, Bank Syariah terdiri dari dua kata yaitu bank dan syariah, maka untuk mendefinisikan Bank Syariah perlu penjabaran masing-masing dari kedua kata tersebut. Secara etimologis atau bahasa istilah bank berasal dari bahasa Italia "Banco" yang artinya adalah bangku. Bangku ini digunakan para pegawai bank untuk melayani aktivitas operasionalnya kepada para penabung. (Iska, 2012:11)

Sedangkan secara terminologi atau istilah, bank adalah badan usaha yang menghimpun dana dari masyarakat dalam benyuk simpanan dan menyalurkannya kepada masyarakat alam bentuk kredit dan/atau bentuk lainnya dalam rangka meningkatkan taraf hidup rakyat. (Pasal 1 ayat (2) UU. No. 21 Tahun 2008 tentang Perbankan Syariah). Sementara itu, kata al-Syari'ah diartikan oleh para ulama dengan ungkapan:

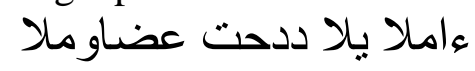

"Jalan menuju sumber air." (Sumitra, 2010: 60)

Secara terminologi, syariah adalah jalan yang ditetapkan Tuhan yang membuat manusia harus mengarahkan kehidupannya untuk mewujudkan kehendak Tuhan agar hidupnya bahagia di dunia dan akhirat. Sedangkan menurut Manna al-Qathan yang dimaksud dengan syariah adalah segala ketentuan Allah swt. yang disyariatkan bagi hamba-hamba-Nya baik yang menyangkut akidah, ibadah, akhlak, maupun juga muamalah. (S. Praja, 1995: 10)

Syariah merupakan pedoman, mengatur hidup manusia sebagai individu, yaitu hamba yang harus taat, tunduk dan patuh kepada Allah swt. ketaatan dan ketundukan tersebut ditunjukkan dengan cara melaksanakan ibadah yang tata caranya telah diatur sedemikian rupa dalam berbagai aturan yang disebut dengan syariah. Syariah juga mengatur hubungan antara manusia dengan dirinya sendiri untuk mewujudkan sosok individu yang saleh dan mencerminkan sosok pribadi yang sempurna. Syariah mengatur hubungan interaksi antara satu individu dengan individu lainnya. Syariah juga mengatur interaksi seorang manusia kepada alam dan lingkungannya.

Ketika kedua kata ini digabungkan menjadi sebuah istilah Bank Syariah, maka pengertiannya adalah bank yang menjalankan kegiatan usahanya berdasarkan prinsip syariah dan menurut jenisnya terdiri atas Bank Umum Syariah dan Bank Pembiayaan Rakyat Syariah. (Pasal

1 ayat (7) UU No. 21 Tahun 2008 tentang Perbankan Syariah) Bank Umum Syariah (BUS) adalah bank syariah yang dalam kegiatannya memberikan jasa dalam lalu lintas pembayaran. (Pasal 1 ayat (8) UU No. 21 Tahun 2008 tentang Perbankan Syariah).

Menurut Wahbah Zuhaily Pakar Fiqh alumnus Universitas Al-Azhar Kairo, Perbankan Islam adalah bank-bank atau lembaga-lembaga keuangan Islami. Yang beraktivitas dan bergerak dalam hal usaha pengumpulan dana, asset, invstasi, dan menumbuh-kembangkan asset tersebut dengan tujuan untuk menjaga kemaslahatan dan kebutuhan para nasabah atau mitra bank. Tidak sebatas perkara yang berkaitan dengan nasabah. Akan tetapi bank Islam juga berupaya dalam bidang social masyarakat untuk mengembalikan masyarakat muslim yang madani, peralisasian ta'âwun islami (saling membantu sesama muslim) dengan memberikan asuransi bantuan (at ta'mîn at taâwuni) dan zakat. Yang semua gerak dan aktivitas lembaga-lembaga Pendanaan Islami tersebut sesuai dengan ushul (prinsip dasar), ahkam (hukum) dan landasan-landasan Islam yang benar. Dan dapat didefinisikan juga sebagai sebuah lembaga keuangan yang menjalankan segala prinsip-prinsip kerja perbankan modern, sesuai dengan cara-cara dan metode-metode terbaru, untuk memudahkan transaksi perdagangan, menyuburkan dana daya investasi dan mempercepat laju perkembangan ekonomi dan social, dengan syarat tidak bertentangan 
dengan hukum-hukum syara'. Sebagai contoh misalnya, pola bagi hasil menggantikan pola bunga bank, pala saham lebih dikedepankan oleh Bank Syariah dari pada pola sekuritas surat berharga. (Zuhaily, 2002: 11)

Beberapa prinsip dasar kerja Bank Syariah yang terpenting adalah sebagai berikut:

1. Pelarangan riba membuang jauh segala bentuk, macam dan jenis praktek yang mengandung unsur riba tersebut.

2. Menyingkirkan praktek transaksi-transaksi kotor dan yang mengandung gharar (penipuan/spekulasi) dan bentuk-bentuk lain yang dilarang oleh syariah.

3. Melarang bentuk transaksi jual beli seperti; transaksi jual beli barang yang belum ada di tangan dan belum diserahkan (belum diqabadh), bai' ma'dum (transaksi jual beli yang barangnya tidak ada), ma'juz taslim (objek tranasksi atau barangnya tidak dapat diserahkan, dan buyu 'ajilah dan mustaqbaliyah yang lepas dari prinsip dasar syariah Islam.

4. Pembagian seluruh jumlah profit atau keuntungan yang berdasarkan pada kesepakatan.

5. Studi dan penerapan teori-teori ekonomi Islam. Sehingga dibentuknya Asosiasi Bank-Bank Islam (Association of Islamic Banks) sebagai badan konsultatif untuk masalah-masalah ekonomi dan perbankan syariah.

6. Tidak menghambat kebutuhan orang yang sangat membutuhkan (mudhthar) dengan cara kesploitasi. Atau mengambil 'iwadh (ganti rugi) tanpa dibarengi usaha.

7. Membantu mereka yang dalam kesusahan dengan cara memberikan pinjaman (qarad hasan) dengan cara yang tepat dan benar.

8. Mengajak pengaplikasian dan realisasi Syariah Islam dalam bidang ekonomi, sosial dan budaya, yang mengantarkan kepada pembaharuan dan gerakan Fikih Islam dengan cara berijtihad yang tidak terpaku pada satu mazhab saja.
Jadi, bank syariah adalah bank yang berdasarkan prinsip syariah (baca: hukum Islam) yang dalam operasional kegiatannya di Negara Kesatuan Republik Indonesia bersandar kepada fatwa Dewan Syariah Nasional Majelis Ulama Indonesia (DSNMUI).

\section{Metode Penelitian}

Jenis penelitian yang akan dilaksanakan adalah penelitian kausal (causal). Penelitian kausal yaitu penelitian yang bertujuan untuk mengukur hubungan antara variable atau untuk menganalisa bagaimana pengaruh suatu variable terhadap variable lainnya (Umar, 2008). Sedangkan metode pengumpulan data adalah metode survey. Metode survey adalah pengumpulan data primer yang diperoleh langsung dari sumber asli (Ghozali dan Ikhsan, 2006). Teknik pengumpulan data menggunakan kuisioner kepada sampel penelitian. Sugiyono (1999:135) menyebutkan "kuisioner merupakan teknik pengumpulan daya yang dilakukan dengan cara memberi seperangkat pertanyaan atau pernyataan tertulis kepada responden untuk dijawabnya. Responden pada penelitian ini adalah nasabah pada Bank BRI Syariah Kc. S.Parman dimana penentuan sample dilakukan dengan teknik Purposive Sampling (sampel pertimbangan) pada nasabah tabungan Mudharobah sebanyak 100 orang. Jumlah 100 orang ini penulis anggap dapat mewakili dan menjawab rumusan penelitian ini. Selanjutnya dilakukan pengumpulan data melalui kuisioner untuk kemudian diolah dengan menggunakan alat bantu pengolahan data untuk menjawab dugaan dari penelitian ini.

\section{Hasil Penelitian}

\section{Karakteristik Penelitian}

Berdasarkan data yang telah dikumpulkan, maka diperoleh data penelitian sebagai berikut: 


\begin{tabular}{llllll}
\hline Variabel & $\mathrm{N}$ & Minimum & Maksimum & Mean & Std. Deviation \\
\hline Religiusitas & 79 & 2.86 & 5,00 & 4.1640 & 0.53537 \\
Persepsi Nasabah & 79 & 2.56 & 4.89 & 3.8497 & 0.52756 \\
Keputusan Memilih & 79 & 2.90 & 5,00 & 4.0203 & 0.37155 \\
\hline
\end{tabular}

Sumber : Hasil penelitian tahun 2017 (diolah)

Hasil diskripsi statistik menyatakan bahwa dari variabel religiusitas, persepsi nasabah, dan keputusan memilih yang memiliki nilai rata-rata terendah adalah pada variabel persepsi nasabah yaitu 3,8497sedangkan standar devisiasi 0,52756.

Nilai religiusitas 4,1640, persepsi nasabah 3,8497 dan keputusan memilih 4,0203. Dengan demikian dapat disimpulkan bahwa secara simultan keputusan memilih produk mudharabah dipengaruhi oleh persepsi nasabah. Hal ini ditunjukkan dengan nilai yang barada diatas nilai rata-rata persepsi nasabah, tetapi nilai keputusan memilih berada dibawah nilai rata-rata religiusitas. Secara parsial yang paling baik adalah religiusitas dengan nilai rata-rata 4,1640 .

Nilai religiusitas 4,1640, persepsi nasabah 3,8497 dan keputusan memilih 4,0203. Dengan demikian dapat disimpulkan bahwa secara simultan keputusan memilih produk mudharabah dipengaruhi oleh persepsi nasabah. Hal ini ditunjukkan dengan nilai yang barada diatas nilai rata-rata persepsi nasabah, tetapi nilai keputusan memilih berada dibawah nilai rata-rata religiusitas. Secara parsial yang paling baik adalah religiusitas dengan nilai rata-rata 4,1640.

\section{Analisis Data}

Sebelum dilakukan pengujian data baik untuk diskripsi data penelitian dan untuk pengujian asumsi klasik serta pengujian hipotesis, maka perlu dilakukan uji validitas dan reliabilitas data.Uji ini perlu dilakukan karena jenis data penelitian adalah primer. Uji validitas data dilakukan dengan membandingkan nilai $r$ hitung dengan $r$ tabel untuk alpha 5\% dan df =n-2 yakni 0,2213. Nilai $\mathrm{r}$ tabel pada penelitian ini untuk $\mathrm{N}$ sebanyak $79(\mathrm{df}=77)$ dan $\mathrm{P}=0,05$ adalah sebesar) 0,2213 (Santoso, 2001), sehingga nilai ini akan digunakan sebagai pembanding dengan nilai $r$ hitung yang diperoleh dari pengolahan dengan menggunakan SPSS. Berdasarkan hasil uji validitas ditemukan ada beberapa butir pertanyaan yang tidak valid, dengan demikian butir tersebut dibuang. Dari variabel religiusitas dati 10 butir pertanyaan 3 diantaranya tidak valid sehingga tidak dipakai dalam penelitian ini sedangkan dari 10 butir pertanyaan variabel persepsi nasabah 1 butir pertanyaan tidak valid dan tidak diikutkan dalam pembahasan penelitian ini. Untuk variabel keputusan memilih 10 pertanyaan semuanya valid.

Setelah data yang tidak valid dibuang maka dilakukan tes validitas ulang sehingga dapat disimpulkan bahwa seluruh item pertanyaan untuk mengukur masing-masing variabel penelitian dinyatakan valid, hal ini dapat dilihat bahwa $r$ hitung lebih besar dari $r$ tabel. Dimana nilai $r$ tabel untuk sampel sebanyak 79 adalah 0,2213 . Setelah dilakukan uji validitas, langkah selanjutnya adalah melakukan uji reliabilitas data yaitu dengan melihat nilai cronbach's alpha lebih besar 0,6 menurut Santoso (2001), jika alpha hitung lebih besar dari alpha tabel dengan nilai positif maka instrument penelitian dapat disebut reliable. 


\section{Uji Validitas Data}

\begin{tabular}{l|l|l|l|l}
\hline Variabel & Butir Instrumen & $\mathrm{r}$ hitung & $\mathrm{r}$ tabel & Keterangan \\
\hline Keputusan Memilih & K1 & 0.299 & 0.2213 & Valid \\
Tabungan Mudharobah & K2 & 0.235 & 0.2213 & Valid \\
(Variabel Dependen) & K3 & 0.275 & 0.2213 & Valid \\
& K4 & 0.534 & 0.2213 & Valid \\
& K5 & 0.388 & 0.2213 & Valid \\
& K6 & 0.541 & 0.2213 & Valid \\
Religiusitas & K7 & 0.397 & 0.2213 & Valid \\
(Variabel Independen 1) & K8 & 0.436 & 0.2213 & Valid \\
& K9 & 0.265 & 0.2213 & Valid \\
& K10 & 0.402 & 0.2213 & Valid \\
\hline & R1 & 0.519 & 0.2213 & Valid \\
& R2 & 0.634 & 0.2213 & Valid \\
& R3 & 0.723 & 0.2213 & Valid \\
& R4 & 0.624 & 0.2213 & Valid \\
& R5 & 0.715 & 0.2213 & Valid \\
& R6 & 0.774 & 0.2213 & Valid \\
(Variabel Independen 2) & R7 & 0.415 & 0.2213 & Valid \\
\hline & PN1 & 0.668 & 0.2213 & Valid \\
& PN2 & 0.705 & 0.2213 & Valid \\
& PN3 & 0.502 & 0.2213 & Valid \\
& PN4 & 0.597 & 0.2213 & Valid \\
& PN5 & 0.623 & 0.2213 & Valid \\
& PN6 & 0.370 & 0.2213 & Valid \\
& PN7 & 0.490 & 0.2213 & Valid \\
& PN8 & 0.520 & 0.2213 & Valid \\
& PN9 & 0.514 & 0.2213 & Valid \\
\hline
\end{tabular}

Sumber : hasil penelitian tahun 2017 (data diolah)

Uji Realiabilitas Data

\begin{tabular}{|l|l|l|l|}
\hline \multicolumn{1}{|c|}{ Variabel } & \multicolumn{1}{|c|}{ Cronbach's } & \multicolumn{1}{c|}{ Batas } & Keterangan \\
& \multicolumn{1}{|c|}{ Alpha } & Realibilitas & \\
\hline Keputusan Memilih Tabungan Mudharobah & 0.714 & 0.6 & Reliabel \\
Religiusitas & 0.841 & 0.6 & Reliabel \\
Persepsi Nasabah & 0.859 & 0.6 & Reliabel \\
\hline
\end{tabular}

Sumber : hasil penelitian tahun 2017 (data diolah) 


\section{Hasil Analisis Data Pengujian Hipotesis}

Setelah dilakukan pengujian asumsi klasik dan diperoleh kesimpulan bahwa model sudah digunakan untuk melakukan pengujian analisa regresi berganda, maka langkah selanjutnya adalah melakukan pengujian hipotesis.

Hipotesis yang akan diuji adalah pengaruh religiusitas dan persepsi nasabah terhadap terhadap keputusan memilih Bank Syariah.

Ringkasan pengujian Hipotesis

\begin{tabular}{|c|c|c|c|c|c|}
\hline \multirow[t]{2}{*}{ Model } & \multicolumn{2}{|c|}{$\begin{array}{c}\text { Unstandardized } \\
\text { Coefficients }\end{array}$} & \multirow{2}{*}{$\begin{array}{c}\begin{array}{c}\text { Standardized } \\
\text { Coefficients }\end{array} \\
\text { Beta } \\
\end{array}$} & \multirow[t]{2}{*}{$t$} & \multirow[t]{2}{*}{ Sig. } \\
\hline & B & Std. Error & & & \\
\hline (Constant) & 2.700 & 0.323 & & 8.351 & 0.000 \\
\hline${ }^{1}$ RELIGIUSITAS & 0.209 & 0.094 & 0.301 & 2.219 & 0.029 \\
\hline PERSEPSI NASABAH & 0.117 & 0.096 & 0.166 & 1.224 & 0.225 \\
\hline
\end{tabular}

a. Dependent variabel ; KPengDan

b. Sumber: hasil penelitian 2017 (data diolah)

\section{Pengujian Hipotesis dengan nilai $\mathbf{F}$}

Nilai $\mathrm{F}$ dapat digunakan untuk menilai goodness of fit suatu model penelitian. Dari Uji Anova atau $F$ test. Didapat $F$ hitung dengan tingkat signifikan 0,000 . Karena probabilitas 0,000 lebih kecil dari 0,05, maka dari model regresi menunjukkan bahwa ada pengaruh Pengaruh religiusitas dan persepsi nasabah terhadap terhadap keputusan memilih Bank Syariah. Dengan kata lain, model regresi layak dipakai untuk memprediksi keputusan memilih berdasarkan masukan variabel religiusitas dan persepsi nasabah.

Dari uraian tersebut dapat diambil kesimpulan bahwa ada pengaruh Pengaruh religiusitas dan persepsi nasabah terhadap terhadap keputusan memilih Bank Syariah secara bersama-sama.

\section{Pengujian Hipotesis dengan uji T}

Untuk melihat pengaruh masingmasing variabel independen secara parsial terhadap keputusan memilih, maka dapat dilihat $t$ hitung dan signifikansi dari nilai $t$ hitung tersebut. Jika nilai signifikansi dari $t$ hitung tersebut lebih kecil dari 0,05 maka dapat dinyatakan bahwa ada pengaruh variabel tersebut terhadap keputusan memilih Bank Syariah. Untuk mengetahui pengaruh variabel independen secara parsial terhadap variabel dependen dengan tingkat kepercayaan 95\% atau pada alpha 5\% dengan syarat apabila nilai variabel independen signifikan terhadap variabel dependen maka terdapat pengaruh antara variabel independen terhadap variabel dependen, sedangkan apabila tidak signifikan maka tidak terdapat pengaruh antara variabel independen terhadap variabel dependen. Pada penelitian ini uji t digunakan untuk menguji apakah hipotesis yang digunakan dalam penelitian ini diterima atau tidak dengan mengetahui apakah variabel independen secara individual mempengaruhi variabel dependen. Adapun metode dalam penentuan $\mathrm{t}$ tabel menggunakan ketentuan tingkat signifikan $5 \%$, dengan $k-1$ (pada penelitian ini $\mathrm{df}=79-2-1=76$ ), sehingga didapat nilai t tabel sebesar 1,992.

Nilai $t$ hitung dari masing-masing variabel independen. Hasil tersebut kemudian dibandingkan dengan nilai t tabel. Variabel independen yang memiliki nilai t hitung lebih besar dari t tabel adalah variabel religiusitas sebesar 2,219. Dengan demikian tolak $\mathrm{H}_{0}$, variabel religiusitas berpengaruh terhadap keputusan memilih. Sedangkan untuk variabel persepsi nasabah memiliki nilai $\mathrm{t}$ hitung dibawah $\mathrm{t}$ tabel yaitu sebesar 1,224 
dengan kata lain terima $\mathrm{H}_{0}$, persepsi nasabah tidak berpegaruh signifikan terhadap keputusan memilih bank syariah.

Selain itu pengujian hipotesis secara parsial juga dapat dianalisis dari nilai signifikansi dimana nilai signifikansi berada dibawah 0,05 maka dapat dikatakan bahwa secara parsial masing-masing variabel bebas berpengaruh siginifikan pada tingkat alpha 5\%. Dari tabel diatas variabel religiusitas memiliki pengaruh signifikan, sedangkan variabel persepsi nasabah tidak berpengaruh signifikan .

\section{Hasil Persamaan Regresi}

Untuk mempermudah pembacaan hasil dan interpretasi analisis regresi maka digunakan bentuk persamaan. Persamaan atau model tersebut berisi konstanta dan koefisien-koefisien regresi yang didapat dari hasil pengolahan data yang telah dilakukan sebelumnya. Persamaan regresi yang telah dirumuskan kemudian dengan bantuan program pengolah data, dilakukan pengolahan sehingga didapat persamaan akhir sebagai berikut:

$$
Y=2,700+0,029 X_{1}+0,117 X_{2}
$$

Dimana:

$\mathrm{X}_{1}=$ Religiusitas

$\mathrm{X}_{2}=$ Persepsi nasabah

Pada model regresi ini, nilai konstanta yang tercantum sebesar 2,700 dapat diartikan jika variabel bebas dalam model diasumsikan sama dengan nol, secara rata-rata variabel diluar model tetap akan meningkatkan keputusan memilih sebesar 2,700 satuan.

Nilai besaran koefisien regresi $\beta$, sebesar 0,029 pada penelitian ini dapat diartikan bahwa variabel relgiusitas $\left(\mathrm{X}_{1}\right)$ berpengaruh positif terhadap keputusan memilih (Y). Hal ini menunjukkan bahwa religiusitas mengalami peningkatan sebesar satu satuan, keputusan memilih juga akan mengalami peningkatan sebesar 0,029 satuan
Nilai besaran koefisien regresi $\beta 2$ sebesar 0,117 pada penelitian ini dapat diartikan bahwa variabel persepsi nasabah $\left(\mathrm{X}_{2}\right)$ berpengaruh positif terhadap keputusan memilih (Y).

\section{Analisis Koefisien Determinasi $\left(\mathbf{R}^{2}\right)$}

Nilai R pada intinya untuk mengukur seberapa besar hubungan antara independent variabel dengan dependent variabel. Berdasarkan hasil pengujian diperoleh nilai $\mathrm{R}$ sebesar 0,427, hal ini menunjukkan bahwa variabel partisipasi religiusitas dan persepsi nasabah mempunyai hubungan yang kuat dengan keputusan memilih bank syariah.

Sedangkan nilai $\mathrm{R}$ square $\left(\mathrm{R}^{2}\right)$ atau nilai koefisien determinasi pada intinya mengukur seberapa jauh kemampuan model dalam menerangkan variasi variabel dependen.Nilai $\mathrm{R}^{2}$ adalah diantara nol dan satu. Nilai $\mathrm{R}^{2}$ yang kecil berarti kemampuan variabel-variabel independen dalam menjelaskan variasi variabel dependent sangat terbatas. Nilai yang mendekati satu berarti variabel-variabel independent memberikan hampir semua informasi yang dibutuhkan untuk memprediksi variasi variabel dependent.Secara umum $\mathrm{R}^{2}$ untuk data silang (crossection) relative rendah karena adanya variasi yang besar antara masing-masing pengamatan, sedangkan untuk data runtun (time series) biasanya mempunyai koefisen determinasi yang tinggi. Kelemahan yang mendasar dengan menggunakan $\mathrm{R}^{2}$ adalah bias terhadap jumlah independen variabel yang dimasukkan dalam model. Setiap ada penambahan satu independen variabel, maka $\mathrm{R}^{2}$ pasti meningkat, tidak perduli apakah variabel tersebut berpengaruh secara signifikan terhadap dependent variabel. Oleh karena itu, beberapa peneliti menganjurkan untuk menggunakan nilai adjusted $\mathrm{R}^{2}$ pada saat mengevaluasi (Ghozali,2013).

Besarnya koefisien determinasi $\left(\mathrm{R}^{2}\right)$ sebesar 0,183(18,3 \%). Sehingga dapat dikatakan $\left(\mathrm{R}^{2}\right)$ bahwa $18.3 \%$ variabel terikat yaitu keputusan memilih bank syariah pada model dapat diterangkan oleh variabel bebas yaitu religiusitas $\left(\mathrm{X}_{1}\right)$, persepsi nasabah $\left(\mathrm{X}_{2}\right)$, 
sedangkan sisanya sebesar 81,7 \% dipengaruhi oleh variabel lain di luar model.

\section{Pembahasan Hasil Penelitian}

Pada pengujian hipotesis berdasarkan hasil perhitungan dapat dikatakan bahwa religiusitas dan persepsi nasabah secara simultan berpengaruh signifikan terhadap keputusan memilih bank syariah. Dalam hal ini dapat dilihat semakin tinggi tingkat religiusitas dan persepsi nasabah tentunya memberikan kontribusi pada semakin tinggi keputusan memilih bank syariah.

Secara parsial persepsi nasabah tidak berpengaruh secara signifikan terhadap keputusan memilih bank syariah (Ho diterima), hal ini berarti semakin tinggi persepsi nasabah tidak memberikan kontribusi yang tinggi pada keputusan memilih bank syariah. Variabel religiusitas berpengaruh secara signifikan terhadap keputusan memilih bank syariah (Ho ditolak), hal ini berarti semakin baik atau tinggi religiusitas maka semakin tinggi keputusan memilih bank syariah.

\section{Pengaruh Religiusitas terhadap Keputusan Memilih Bank Syariah}

Penelitian ini menunjukkan pengaruh religiustias terhadap keputusan memilih bank syariah signifikan positif terlihat dari koefisien regresi religiusitas sebesar 0,029 dan signifikan karena nilai $\mathrm{t}$ hitung $>\mathrm{t}$ table (2,219>1,992).

Pengaruh positif menunjukkan bahwa pengaruh religiusitas adalah searah dengan keputusan memilih bank syariah atau dengan kata lain religiusitas yang baik atau tinggi akan berpengaruh terhadap semakin tinggi nasabah dalam mengambil keputusan memilih bank syariah, demikian sebaliknya bila religiusitas rendah/buruk maka keputusan memilih bank syariah juga kan rendah. Tetapi pengaruh positif tidak signifikan, hal ini menunjukkan bahwa religiusitas mempunyai peranan yang penting dalam meningkatkan keputusan memilih bank syariah.

\section{Pengaruh Penggunaan Persepsi nasabah terhadap Keputusan Memilih Bank Syariah}

Penggunaan persepsi nasabah sejauh ini merupakan satu indicator dalam menentukan keputusan nasabah memilih bank syariah. Pada hasil penelitian berdasarkan tabel dibawah ini menunjukkan pengaruh persepsi nasabah terhadap keputusan memilih bank syariah adalah positif.Positif terlihat dari koefisien regresi persepsi nasabah sebesar 0,117 , namun pengaruh tersebut tidak signifikan karena nilai $\mathrm{t}$ hitung < dari t tabel $(1,224<1,992)$.

Pengaruh positif berarti persepsi nasabah memiliki pengaruh yang searah dengan keputusan memilih bank syariah atau dengan kata lain semakin tinggi persepsi nasabah akan semakin berpengaruh terhadap keputusan memilih bank syariah, demikian sebaliknya jika semakin rendah persepsi nasabah maka akan menyebabkan keputusan memilih bank syariah semakin rendah.

\section{Penutup}

Berdasarkan pembahasan hasil penelitian terhadap nasabah BRI Syariah, dapat ditarik kesimpulan bahwa:

1. Secara simultan religiusitas dan persepsi nasabah berpengaruh secara signifikan terhadap keputusan memilih bank syariah. Hipotesis penelitian berdasarkan hasil perhitungan dapat dikatakan bahwa religiusitas, persepsi nasabah berpengaruh signifikan terhadap keputusan memilih bank syariah secara simultan.

2. Secara parsial hanya variabel religiusitas yang memiliki pengaruh positif dan signifikan terhadap keputusan memilih bank syariah, sedangkan variabel persepsi nasabah berpengaruh positif tapi tidak signifikan terhadap keputusan memilih bank syariah. 


\section{Daftar Pustaka}

Abhimantra, A., Maulina, A. R., \& Agustianingsih, E. (2013). Analisis Faktor-Faktor Yang Mempengaruhi Nasabah Menggunakan Layanan Internet. In Proceeding Pesat (Psikologi, Ekonomi, Sastra, Asitektur \& Teknik Sipil) (Vol. 5, pp. 170-177).

Ahmad, N dan Haron, S. 2001. Perception of Malaysian Corporate Customers Toward Islamic Banking Products \& Services, International Journal of Islamic Financial Service, Vol. 3 No. 4.

A. Karim, Adiwarman. 2010. Ekonomi Makro Islam. Jakarta : Rajawali Pers

A. Karim, Adiwarman. 2014. Bank Islam: Analisis Fiqih dan Keuangan. Jakarta: PT Rajagrafindo Persada

Almossawi, M. Bank selection criteria employed by college students in Bahrain: an empirical analysis, The International Journal of Bank Marketing, 1991, Vol.19 No. 3, pp 115

Fadhil Nur Ahmad. 2010. Etika Bisnis. Jakarta: Hijri Pustaka Utama.

Ghozali, Imam. 2013, Aplikasi Analisi Multivariate dengan Program SPSS. Badan Penerbit Universitas Diponegoro, Semarang.

Hanik, S. U., \& Handayani, J. (2014). Keputusan Nasabah Dalam Memilih Perbankan Syariah. Jurnal Akuntansi Dan Perbankan Indonesia, 22 No.2(2), 188-202.

Irbid dan Zakra. 2001. Banking Behaviour of IslamicBank Costumers; Perspective and Implications. International of Bank Marketing. Vo. 16, No. 7,pp. 299-313

Ismail Muhammad Bakar. 2008. Fiqah Lengkap, Kuala Lumpur: Berlian Publication, Jilid I, terj. Muhammad Zuhirsyan dkk.

Ismail Faisal. 2007. Paradigma Kebudayaan Islam, Yogyakarta: Titian Ilahi Press.
Kamsir. 2003. Dasar-dasar Perbankan. Jakarta: PT RajaGrafindo Persada

Levin, Richard L, dan Rubin, David S, 1998. Statistic For Managemnet, $7^{\text {th }}$ edition. Prentice-Hall International, Inc.

Metawa, S. A., \& Almossawi, M. Banking behavior of Islamic bank customers: Perspectives and implications,

Muhammad. 2002. Manajemen Bank Syariah. Yogyakarta: AMP YKPN

Muhammad. 2004. Bank Syariah Analisis Kekuatan, Kelemahan, Peluang dan Ancaman. Yogyakarta: Ekonomis

Nata, Abudin. 2011. Paradigma Pendidikan Islam. Jakarta: Grasindo.

Nikensari, Sri Indah. 2012. Perbankan Syariah. Semarang: Pustaka Rizki Putra

Rivai, H., Luviarman, N., \& Dkk. (2006). Identifikasi Faktor Penentu Keputusan Konsumen dalam Memilih Jasa Perbankan: Bank Syariah vs Bank konvensional. Kerjasama BankIndonesia Dan Center for Banking Research Universitas Andalas, 1-17.

Rohmadi, Nurbaiti, \& Junaidi. (2016). Analisi Faktor Penentu Keputusan Nasabah dalam Memilih Jasa Perbankan Syariah dan Perbankan Konvensional di Kote Bengkulu. Jurnal Munhaj, 4(3), 283-290.

Santoso, Singgih, 2001, SPSS Statisitik Parametrik; Elex Media Komputindo, Jakarta. Sekaran,

Uma. 2011. Metodologi penelitian untuk Bisnis. Jakarta; Salemba empat.

Sugiyono 2012. Metodologi penelitian kuantitati kualitatif dan R \& B. Bandung: Alfabeta

Sugioyono, 1999. Metode Penelitian Bisnis. CV. Alfabeta. Bandung Suhendi, Hendi. 2008. Fiqh Muamalah. Jakarta: PT. RajaGrafindo Persada.

Sukirno, Sadono. 2006. Makro Ekonomi Teori Pengantar. Jakarta: PT. RajaGrafindo

Suliyanto. 2011. Ekonometrika Terapan : Teori dan Aplikasi dengan SPSS. Yogyakarta: Andi Offset 
Priyatno, Duwi. 2012. Belajar Cepat Olah Data SPSS. Yogyakarta: Andi Offset Rivai, Veitzal. 2008. Islamic Financial Management. Jakarta, RajaGrafindo Persada

Poerwadarminta, W.J.S. 2011. Kamus Umum Bahasa Indonesia. Jakarta : Balai Pustaka

Rofiq. 2004. Fiqh Konstektual.Yogyakarta : Pustaka Pelajar

Umar, Husein, 2008. Metode penelitian untuk Skripsi dan Tesis Bisnis. Rajawali Pers. Jakarta 